University of Nebraska - Lincoln

DigitalCommons@University of Nebraska - Lincoln

1990

\title{
Degradation of Wheat Streak Mosaic Virus Capsid Protein During Leaf Senescence
}

\author{
Myron K. Brakke \\ University of Nebraska-Lincoln \\ Rose N. Skopp \\ University of Nebraska-Lincoln \\ L. C. Lane \\ University of Nebraska-Lincoln
}

Follow this and additional works at: https://digitalcommons.unl.edu/plantpathpapers

Part of the Plant Pathology Commons

Brakke, Myron K.; Skopp, Rose N.; and Lane, L. C., "Degradation of Wheat Streak Mosaic Virus Capsid Protein During Leaf Senescence" (1990). Papers in Plant Pathology. 179.

https://digitalcommons.unl.edu/plantpathpapers/179

This Article is brought to you for free and open access by the Plant Pathology Department at DigitalCommons@University of Nebraska - Lincoln. It has been accepted for inclusion in Papers in Plant Pathology by an authorized administrator of DigitalCommons@University of Nebraska - Lincoln. 


\title{
Degradation of Wheat Streak Mosaic Virus Capsid Protein During Leaf Senescence
}

\author{
Myron K. Brakke, Rose N. Skopp, and L. C. Lane
}

Agricultural Research Service, U.S. Department of Agriculture and Department of Plant Pathology, Nebraska Agricultural Experiment Station, University of Nebraska, Lincoln 68583-0722.

Cooperative investigation of the ARS, USDA, and the Nebraska Agricultural Experiment Station. Research conducted under Project 21-3 and published as Journal Paper 9372 of the Nebraska Agricultural Experiment Station.

Mention of a trademark or proprietary product does not constitute a guarantee or warranty by the U.S. Department of Agriculture and does not imply approval to the exclusion of other products that may also be suitable.

The technical assistance of Richard Samson, Sue Field, and Diane Hooper is gratefully acknowledged.

Accepted for publication 23 January 1990 (submitted for electronic processing).

\section{ABSTRACT}

Brakke, M. K., Skopp, R. N., and Lane, L. C. 1990. Degradation of wheat streak mosaic virus capsid protein during leaf senescence. Phytopathology $80: 1401-1405$.

\begin{abstract}
Wheat streak mosaic virus capsid protein degraded in vivo by proteolysis as leaves senesced. The capsid protein of virus purified from young systemically infected leaves had an apparent size of $45 \mathrm{kDa}$ in $12 \%$ sodium dodecyl sulfate-polyacrylamide gels with minor amounts of $43,42,33$, and $31 \mathrm{kDa}$ proteins. The proportion of smaller proteins increased with the age of the leaf. In some virus preparations only $31 \mathrm{kDa}$ capsid protein was detected. In vitro proteolysis of virions with $45 \mathrm{kDa}$ protein produced virions with $31 \mathrm{kDa}$ protein. Virions with $31 \mathrm{kDa}$ capsid protein sedi-
\end{abstract}

Additional keywords: gel electrophoresis, potyviruses. mented slightly more slowly than those with $45 \mathrm{kDa}$ protein. Antiserum to intact virions, containing predominantly $45 \mathrm{kDa}$ protein, reacted with both 45 and $31 \mathrm{kDa}$ proteins on Western blots. Thirteen isolates of WSMV could be classified into two groups with major capsid proteins of 47 and $45 \mathrm{kDa}$, respectively, as well as accompanying minor proteins. Most natural isolates, including Sidney 81 , contained $45 \mathrm{kDa}$ protein, but the type strain contained $47 \mathrm{kDa}$ protein.
Wheat streak mosaic virus (WSMV) causes a serious disease of winter wheat in North America, Jordan, and Europe (5). The virus resembles potyviruses in morphology and by inducing cylindrical or pinwheel-shaped cytoplasmic inclusions containing a 66 $\mathrm{kDa}$ protein, but differs from classical potyviruses in being transmitted by an eriophyid mite, Eriophyes tulipae Keifer (4,7). Potyviruses usually have a capsid protein ranging in size from 28 to $40 \mathrm{kDa}$ accompanied by varying amounts of smaller proteins $(13,20)$. Detailed examination of the smaller proteins indicates they arise from degradation of the largest protein $(12,20)$. Our preliminary estimates of capsid protein size by sodium dodecyl sulfate-polyacrylamide gel electrophoresis varied. A $45 \mathrm{kDa}$ protein predominated in most virus preparations, but a $31 \mathrm{kDa}$ protein predominated in others. Most preparations had both 45 and 31 $\mathrm{kDa}$ proteins, as well as proteins of intermediate size. Proportions of the various proteins were erratic. To investigate these inconsistencies we systematically studied the protein composition of several strains of WSMV and investigated the effect of proteases on the virion.

\section{MATERIALS AND METHODS}

Materials. Enzymes, enzyme inhibitors, enzyme-coupled antibody, and chemicals for developing Western blots were obtained from Sigma Chemical Co., St. Louis, MO.

Virus maintenance and assay. Most experiments were done with the type strain of WSMV (PV57; ATCC, 1981) and an isolate collected from western Nebraska in 1981 (Sidney 81). The type isolate was collected in Kansas in 1932 and maintained by $\mathrm{H}$. H. McKinney until 1955, when we obtained it from him. This isolate was transmitted by mites (E. tulipae) with the assistance of R. Staples just before it was contributed to the ATCC collection.

\footnotetext{
This article is in the public domain and not copyrightable. It may be freely reprinted with customary crediting of the source. The American Phytopathological Society, 1990.
}

One experiment employed 11 additional isolates collected in Nebraska between 1956 and 1985. These isolates were kept in dried leaves at $2 \mathrm{C}$ over $\mathrm{CaCl}_{2}$ and rejuvenated by passage through plants every 4-5 yr. Virus was grown and purified from Michigan Amber wheat. It was generally inoculated at the two-leaf stage and plants were harvested when five or six leaves were fully expanded.

Infectivity assays of WSMV and its RNA were based on systemic infection of wheat (Triticum aestivum L. 'Michigan Amber') plants inoculated with a series of dilutions (2). The sizes of virions and viral RNA were estimated by density gradient centrifugation $(3,6,8)$.

Leaf age. Leaves were harvested for purification from plants with five to six fully expanded leaves. Where age of the infection was important, we used plants that were simultaneously inoculated and combined leaves of similar physiological ages from several plants. For this purpose the youngest fully expanded leaf is designated as the first leaf and older leaves are numbered downward in order of increasing age.

Virion and RNA purification. Virions were purified by grinding infected wheat leaves in a blender with two volumes $(\mathrm{ml} / \mathrm{g})$ of $10 \mathrm{mM} \mathrm{K}_{2} \mathrm{HPO}_{4}$, adjusting the $\mathrm{pH}$ to 6.1 with $1 \mathrm{M}$ acetic acid, and centrifuging the extract at $10,000 \mathrm{rpm}$ in a Sorvall SS34 rotor for $15 \mathrm{~min}$. The supernatant was adjusted to $\mathrm{pH} 7.5-8.0$ with $\mathrm{NaOH}$ and brought to $10 \mathrm{mM}$ in trisodium citrate and $1 \%$ $(\mathrm{v} / \mathrm{v})$ in Triton $\mathrm{X}-100$. The extract was centrifuged for $1.8 \mathrm{hr}$ at $27,000 \mathrm{rpm}$ at $5 \mathrm{C}$ in a Beckman No. 30 rotor through a 4-ml pad of $20 \%$ (w/v) sucrose in $10 \mathrm{mM}$ trisodium citrate, $\mathrm{pH}$ 8.0. Pellets were suspended in $10 \mathrm{mM}$ trisodium citrate $(\mathrm{pH} 8)$ and clarified by centrifugation for $5 \mathrm{~min}$ at $5,000 \mathrm{rpm}$ in a Sorvall SS34 rotor. For density gradient centrifugation of virions, samples $(2-4 \mathrm{ml})$ were floated on linear $10-40 \%(\mathrm{w} / \mathrm{v})$ sucrose gradients prepared in $10 \mathrm{mM}$ trisodium citrate and centrifuged for $3 \mathrm{hr}$ at $25,000 \mathrm{rpm}$ at $5 \mathrm{C}$ in a Beckman SW27 rotor.

To extract RNA from the virus, portions of the preparation were diluted with equal volumes of $2 \times \mathrm{AAE}$ buffer (1X AAE is $100 \mathrm{mM}\left[\mathrm{NH}_{4}\right]_{2} \mathrm{CO}_{3}, 300 \mathrm{mM} \mathrm{NH}_{4} \mathrm{Cl}, 2 \mathrm{mM}$ ethylene diamine tetraacetic acid [EDTA], adjusted to $\mathrm{pH} 9.3$ with $\mathrm{NaOH}$ ) 
containing $2 \%(\mathrm{w} / \mathrm{v})$ SDS and $400 \mu \mathrm{g} / \mathrm{ml}$ bentonite. After incubation for $16 \mathrm{hr}$ at $2 \mathrm{C}$ or for $30 \mathrm{~min}$ at $25 \mathrm{C}$, the solution was floated on a linear $7.5-30 \%(\mathrm{w} / \mathrm{v})$ sucrose gradient prepared in $1 \times$ AAE buffer and centrifuged for $5 \mathrm{hr}$ at $36,000 \mathrm{rpm}$ at $14 \mathrm{C}$ in the Beckman SW41 rotor. Centrifuged gradients were scanned for absorbance of $254 \mathrm{~nm}$ light with an ISCO Model UA 5 Fractionator and Densitometer.

In vitro proteolysis. WSMV was purified by the above method and its concentration was adjusted to $1.0 \mathrm{mg} / \mathrm{ml}$ (assuming an absorbancy of $3 \mathrm{~cm}^{2} / \mathrm{mg}$ for SDS dissociated virus). Samples $(50 \mu \mathrm{g})$ were incubated for $1 \mathrm{hr}$ at room temperature with $1 \mu \mathrm{g}$ of trypsin. To prepare samples for a Western blot, proteolysis was stopped by diluting the sample with 1 volume of Laemmli (15) dissociation buffer and heating for $2 \mathrm{~min}$ at $100 \mathrm{C}$. Small aliquots $(3-10 \mu \mathrm{l})$ were electrophoresed on $8-25 \%$ polyacrylamide gels. For density gradient centrifugation of proteolysis products, digestion was stopped by adding $50 \mu \mathrm{g} / \mathrm{ml}$ of Lima bean trypsin inhibitor. Samples were layered on $0-25 \%(w / w)$ linear $/ \log$ sucrose gradients in $100 \mathrm{mM}$ trisodium citrate, $\mathrm{pH} 8.0$, (9) and centrifuged for $1 \mathrm{hr}$ at $35,000 \mathrm{rpm}$ in a Beckman SW41 rotor. Centrifuged gradients were scanned as described above and fractions were collected for protein gel electrophoresis.

Western blotting. Proteins were transferred to nitrocellulose membrane using an ABN Polyblot apparatus (American Bionetics, Inc., Hayward, CA). To prepare the Polyblot, one layer of Whatman No. 1 filter paper soaked in $0.6 \mathrm{M}$ Tris containing $25 \%$ methanol was placed over the positive electrode. A second sheet of filter paper soaked in $0.25 \mathrm{M}$ Tris containing $25 \%$ methanol was layered on top of the first. The membrane soaked in $25 \%$ methanol was placed on the filter papers. The polyacrylamide gel, which had been washed briefly (3-4 sec) with $5 \mathrm{mM}$ Tris, $5 \mathrm{mM} \mathrm{H}_{3} \mathrm{BO}_{4}$ in $25 \%$ methanol, was layered next followed by two additional sheets of Whatman No. 1 filter paper wet with a solution of $0.6 \mathrm{M}$ Tris, $0.6 \mathrm{M} \mathrm{H}_{3} \mathrm{BO}_{4}$ in $25 \%$ methanol. Filter paper, gel, and the membrane must be of the same dimensions and must be aligned with the electrodes to achieve uniform transfer. Proteins were transferred at a current density of 2.5 $\mathrm{mA} / \mathrm{cm}^{2}$ for $45 \mathrm{~min}$.

After transfer, the membrane was washed for $15 \mathrm{~min}$ in Trisbuffered saline (TBS: $10 \mathrm{mM}$ Tris adjusted to $\mathrm{pH} 8.0$ with $\mathrm{HCl}$, $0.1 \mathrm{M} \mathrm{NaCl}$ ) and then incubated for $1 \mathrm{hr}$ in WSMV antiserum (prepared from intact virions) diluted 1:1,000 with a $5 \%(\mathrm{w} / \mathrm{v})$ solution of nonfat dry milk (15) in TBS. Simultaneous incubation with blocking agent and antiserum gave results indistinguishable from sequential incubation. After a brief rinse $(2-3 \mathrm{sec})$ with TBS, the membrane was incubated for $15 \mathrm{~min}$ with the $5 \%$ nonfat dry milk solution. The membrane was then incubated for $1 \mathrm{hr}$ in alkaline phosphatase coupled goat anti-rabbit serum (AP-GAR) diluted 1:1,000 with TBS. This was followed by two 10-min washes in TBS and one in $0.1 \mathrm{M}$ Tris adjusted to $\mathrm{pH} 9.0$ with $\mathrm{HCl}$, $0.1 \mathrm{M} \mathrm{NaCl}, 10 \mathrm{mM} \mathrm{MgCl}$.

The stain was prepared from two stock solutions. Solution A contained $5 \mathrm{mg}$ of nitroblue tetrazolium (NBT, Grade III) in $15 \mathrm{ml}$ of $0.1 \mathrm{M}$ Tris adjusted to $\mathrm{pH} 9.0$ with $\mathrm{HCl}, 0.1 \mathrm{M} \mathrm{NaCl}$, $10 \mathrm{mM} \mathrm{MgCl}_{2}$. Solution B contained $2.5 \mathrm{mg}$ of 5-bromo-4-chloro3 -indolyl phosphate (BCIP, disodium salt) in $2 \mathrm{ml}$ of the $\mathrm{pH}$ 9.0 buffer described above. To stain, $13 \mathrm{ml}$ of solution A was mixed with $2 \mathrm{ml}$ of solution B. The membrane was submerged in a minimal volume of the mixture and incubated overnight to maximize sensitivity. The blot was washed several times in distilled water and subsequently air dried. To prevent photobleaching of the BCIP/NBT stain, the blot was stored in the dark.

Protein gel electrophoresis. Samples from virus zones in sucrose gradient columns were precipitated by adding two volumes of ethanol and incubating at $-20 \mathrm{C}$ for $16 \mathrm{hr}$. Precipitated virus was pelleted by centrifugation, suspended in dissociation buffer, and boiled for $2 \mathrm{~min}$. Unless stated otherwise, the disrupted virus was electrophoresed in $12 \%$ polyacrylamide gels using the discontinuous buffer of Laemmli (16). After electrophoresis, the gels were stained with either Coomassie Brilliant Blue R250 or with silver according to Morrissey (17).

\section{RESULTS}

Variation in apparent size of capsid protein with leaf age. As many as five proteins were observed after gel electrophoresis of purified Sidney 81 strain WSMV (Fig. 1). The relative proportions of these proteins varied from experiment to experiment. Leaf age significantly influenced the proportions of capsid proteins. With one exception, the major protein in virus purified from the first (youngest, fully expanded) wheat leaf had an apparent size of $45 \mathrm{kDa}$. Virus from the second leaf had less $45 \mathrm{kDa}$ protein, and third (older) leaves, had still less (Table 1). In some experiments, the second or third leaves had only $31 \mathrm{kDa}$ protein. The exception was a plant grown at $15 \mathrm{C}$ in a growth chamber whose youngest leaf yielded virus with $31 \mathrm{kDa}$ protein. The distribution of the two sizes of capsid protein was similar whether plants were grown at $15 \mathrm{C}$ or in the greenhouse.

RNA from virions with $31 \mathrm{kDa}$ capsid protein sedimented at the same rate in sucrose gradients as that from virions with 45 $\mathrm{kDa}$ capsid protein (data not shown). In two of three experiments, the RNA assay of preparations from third leaves indicated more virus than did the virion assay of the same preparations (Table 1). Preparations from first and second leaves gave ratios of virions

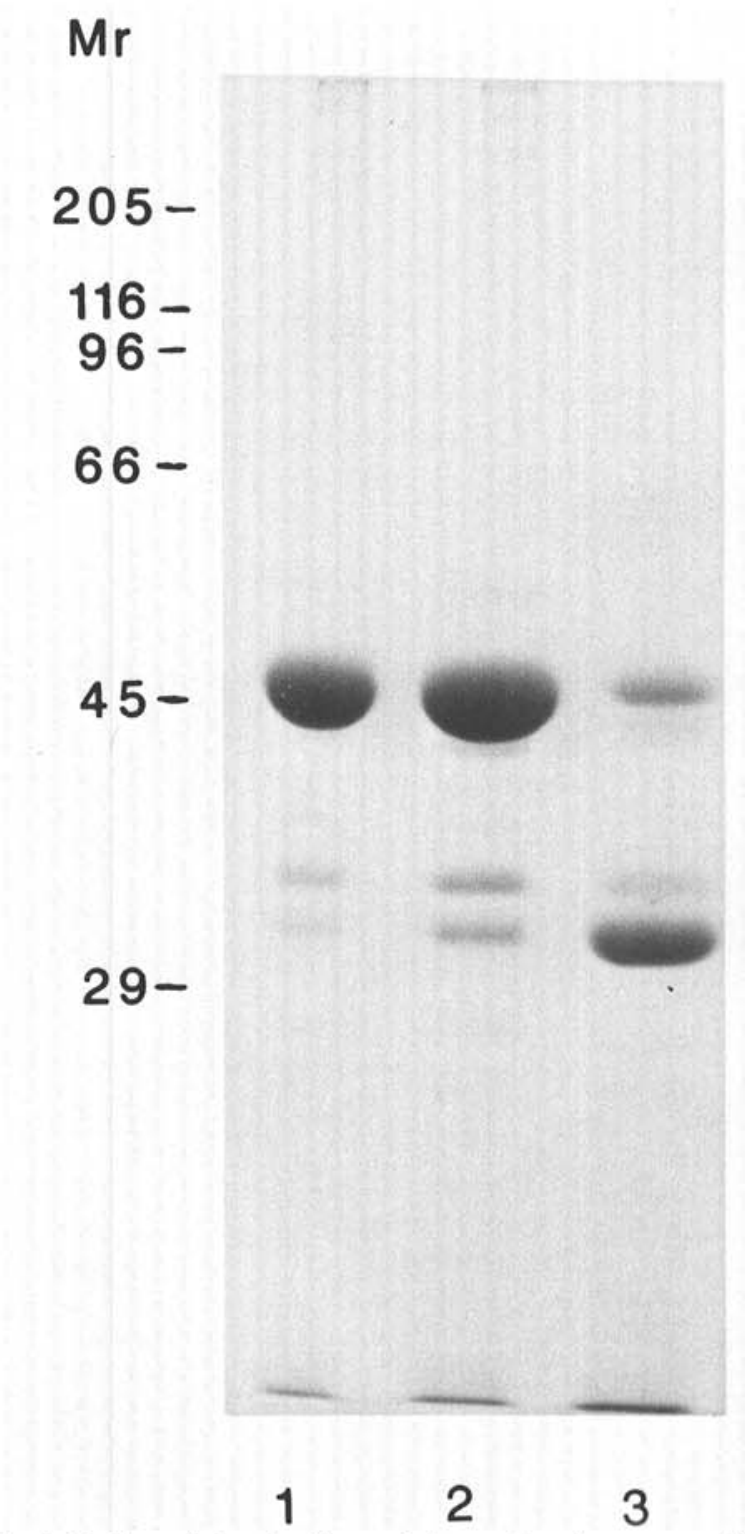

Fig. 1. Sodium dodecyl sulfate-gel electrophoretic pattern of proteins of virus purified from first (lane 1), second (lane 2), and third (lane 3) leaves of plants infected with the Sidney 81 strain of wheat streak mosaic virus. From experiment 4 of Table 1. 
to RNA close to the expected value (virion/RNA ratio of 15-20 for 5-6\% RNA). Lower virion/RNA ratios may reflect instability or aggregation of virions, and higher ratios may reflect degradation of RNA.

Preparations from second and third leaves had lower specific infectivity in three of four experiments than preparations from first (youngest fully expanded) leaves (Table 1). In the one experiment where virus from older (second and third) leaves was as infectious as from first leaves (Table 1), the capsid protein of virus from the third leaves was predominantly $45 \mathrm{kDa}$. In one experiment, the extract from third leaves had no detectable $45 \mathrm{kDa}$ capsid protein. This extract was infectious (Table 1).

Dependence of sedimentation rate of virions on size of capsid protein. Virions containing small capsid protein sedimented 3-5\% more slowly than virions with large capsid protein. Absorbance profiles of gradients with type strain WSMV are shown in Figure 2. Virus purified from the youngest fully expanded leaf gave the profile shown in B, whereas virus purified from the next two older leaves of the same plants gave the profile in $\mathrm{A}$, and a mixture of the two extracts gave the profile in C. Gel electrophoresis showed that the virus from profile A contained $33 \mathrm{kDa}$ protein and that from profile B contained $47 \mathrm{kDa}$ protein (Fig. 2D).

Capsid proteins after proteolysis. Figure 3 shows absorbance profiles of centrifuged sucrose gradients that contained trypsintreated WSMV type strain. Virus purified from the two youngest leaves gave the profile in $\mathrm{A}$; virus purified from young leaves treated with trypsin gave the profile in $\mathrm{B}$; a mixture of the two samples gave the profile in C. Gel electrophoresis (in an $8-25 \%$ gradient gel stained with silver) showed that the virus recovered from gradients with profile A contained $47 \mathrm{kDa}$ protein; that from gradients with profile B contained $31 \mathrm{kDa}$ protein; virus from gradients with profile $C$ contained both 47 and $31 \mathrm{kDa}$ proteins (Fig. 3D). The $31 \mathrm{kDa}$ protein migrated slightly faster than the smallest protein of virions purified from old leaves.

TABLE 1. Infectivities of wheat streak mosaic virus (WSMV) and WSMV RNA preparations

\begin{tabular}{|c|c|c|c|c|c|c|}
\hline \multirow[b]{2}{*}{$\underline{L e a f}$ age $^{a}$} & \multicolumn{2}{|c|}{$\begin{array}{c}\text { Concentration } \\
(\mu \mathrm{g} / \mathrm{g}) \\
\end{array}$} & \multirow{2}{*}{$\begin{array}{l}\text { Infectivity } \\
\text { titer }^{\mathrm{b}}\end{array}$} & \multirow{2}{*}{$\begin{array}{l}\text { Protein } \\
\% 45 \mathrm{~K}^{\mathrm{c}}\end{array}$} & \multicolumn{2}{|c|}{$\begin{array}{c}\text { Specific } \\
\text { infectivity }^{d}\end{array}$} \\
\hline & Virion & RNA & & & Virion & RNA \\
\hline \multicolumn{7}{|c|}{ Experiment 1} \\
\hline First & 4.4 & ND & $3.47+/-0.06$ & 96 & 671 & ND \\
\hline Second & 1.4 & ND & $2.58+1-0.06$ & 86 & 271 & ND \\
\hline Third & 0.9 & ND & $2.51+/-0.06$ & 0 & 360 & ND \\
\hline \multicolumn{7}{|c|}{ Experiment 2} \\
\hline First & 14.6 & 1.33 & $4.00+/-0.18$ & 87 & 685 & 7,519 \\
\hline Secon & 15.8 & 1.40 & $3.77+/-0.07$ & 78 & 372 & 4,206 \\
\hline Third & 6.8 & 0.88 & $3.45+/-0.09$ & 57 & 414 & 3,2 \\
\hline \multicolumn{7}{|c|}{ Experiment 3} \\
\hline First & 15.6 & 0.85 & $3.47+/-0.08$ & 95 & 189 & 3,472 \\
\hline Secon & 36 & 1.47 & $3.98+/-0.09$ & 90 & 265 & 6,496 \\
\hline Third & 19 & 1.07 & $3.76+/-0.08$ & 78 & 303 & 5,3 \\
\hline \multicolumn{7}{|c|}{ Experiment 4} \\
\hline First & 12.3 & 0.75 & 3.9 & 86 & 646 & 10,590 \\
\hline Second & 13.8 & 0.80 & 3.8 & 77 & 457 & 7,890 \\
\hline Third & 2.3 & 0.52 & 3.0 & 31 & 435 & 1,923 \\
\hline
\end{tabular}

a Leaf numbers indicate the age of the leaf from which virus was purified. The first leaf was the youngest fully expanded, the second leaf was the next oldest, and the third leaf was the next oldest after that. All leaves in a single experiment were from the same batch of plants. Approximately $20 \mathrm{~g}$ of leaves were used for each purification. Experiment 1 was done with the type strain, the others with Sidney 81 .

${ }^{b}$ The infectivity titer is the log of the dilution infecting $63 \%$ of the assay plants calculated as specified by Brakke (2). In experiment 4 , all assay plants were infected except for those inoculated with the highest dilution, where $50-80 \%$ were infected. Therefore, a standard deviation was not calculated and the titer was estimated from the highest dilution assuming a slope of one.

${ }^{c}$ Calculated from photometric scanning of Coomassie-stained gels. The figure given is the percentage of the total area of the viral protein peaks that was in the $45 \mathrm{kDa}$ protein peak.

${ }^{\mathrm{d}}$ The antilog of the infectivity titer divided by the micrograms of virions or RNA.
Western blot of proteolysis products. A silver-stained $8-25 \%$ polyacrylamide gel of trypsin treated type strain WSMV is shown in Figure 4A. The control sample of undigested WSMV contained $47 \mathrm{kDa}$ protein and minor amounts of $45,43,35$, and $33 \mathrm{kDa}$ proteins. After trypsin treatment, the major protein shifted to

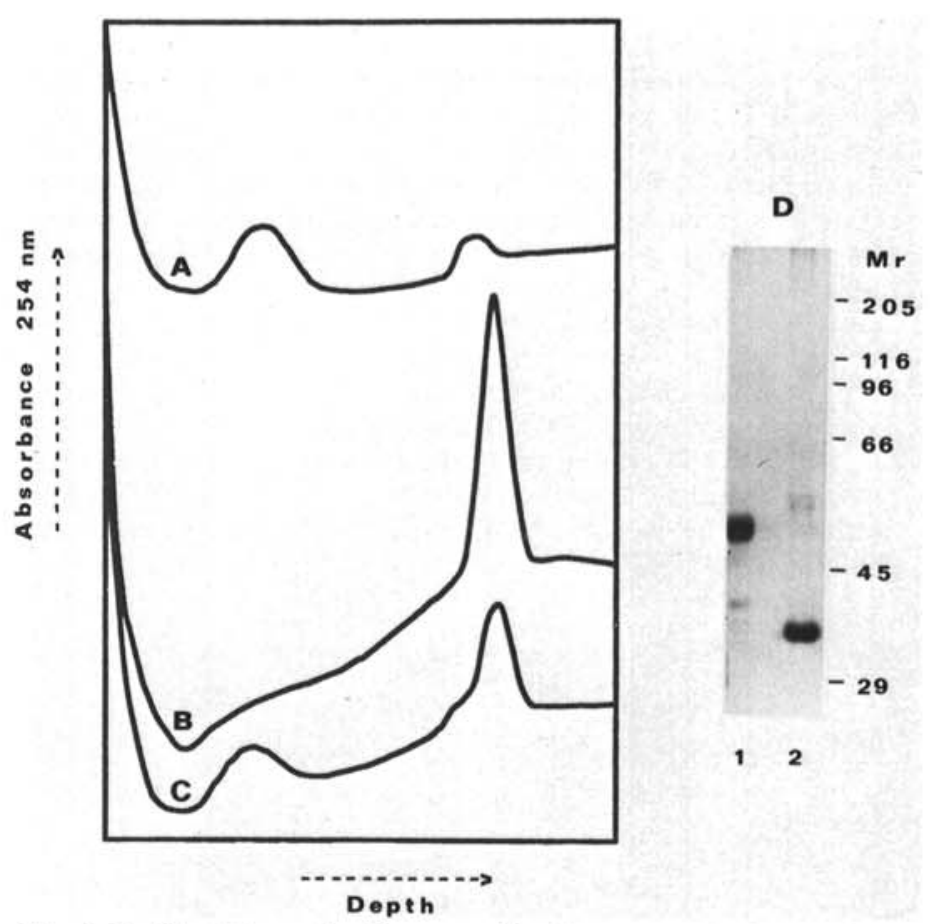

Fig. 2. Profile $A$ is an absorbance profile of a sucrose density gradient after centrifugation of an extract from third leaves infected with wheat streak mosaic virus; profile B is an extract from first (youngest fully expanded) leaves and profile $\mathrm{C}$ is a mixture of the two. Panel D shows Coomassie blue stained sodium dodecyl sulfate-polyacrylamide gel electrophoretic patterns of proteins extracted from the virus zones shown in profile B (lane 1) and in profile A (lane 2).

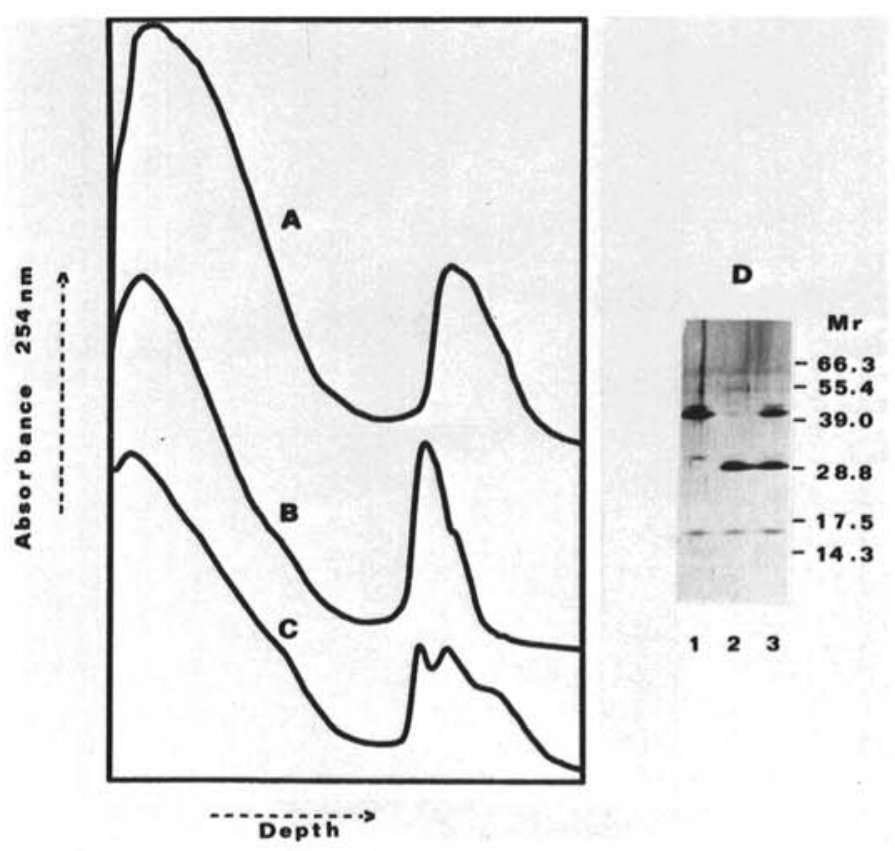

Fig. 3. Absorbance profiles of centrifuged linear-log sucrose density gradients which contained $\mathbf{A}$, purified virions from first (youngest fully expanded) leaves; B, purified virions from first leaves after trypsin treatment; and $\mathbf{C}$, a mixture of the treated and untreated virions. Panel D shows a silver stained $8-25 \%$ polyacrylamide gradient gel of proteins from virus containing zones of gradient A (lane 1) of B (lane 2) and of C (lane 3). The positions of standard proteins are indicated. 
$33 \mathrm{kDa}$. Figure 4B shows a Western blot of these samples. Both the untreated WSMV control (predominantly $47 \mathrm{kDa}$ protein) and trypsin digested virus ( $33 \mathrm{kDa}$ protein) reacted with antisera prepared to virions. Minor proteins also reacted with the antiserum roughly in proportion to their silver staining intensity. In no case did the antiserum react with proteins from sham purifications of healthy tissue or with proteins in purified preparations of soilborne wheat mosaic virus.

Virion capsid protein from individual plants. Virus was purified by density gradient centrifugation from 14 individual plants that were infected by inoculation with sap dilutions of $10^{-4}$ or $10^{-5}$ of type strain. Virus was similarly purified from 14 individual plants inoculated with similar dilutions of the Sidney 81 strain. Fewer than $20 \%$ of the plants became infected after inoculation with these dilutions and, based on the Poisson distribution, more than $80 \%$ of infections should have arisen from single particles. Gel electrophoresis of samples from the virus zones showed a major $45 \mathrm{kDa}$ protein for virus from plants infected with the Sidney 81 strain and a $47 \mathrm{kDa}$ protein for virus from plants infected with the type strain (data not shown). Minor, smaller proteins typical of WSMV were present. The ratios of smaller proteins to the major protein were similar in the different preparations.

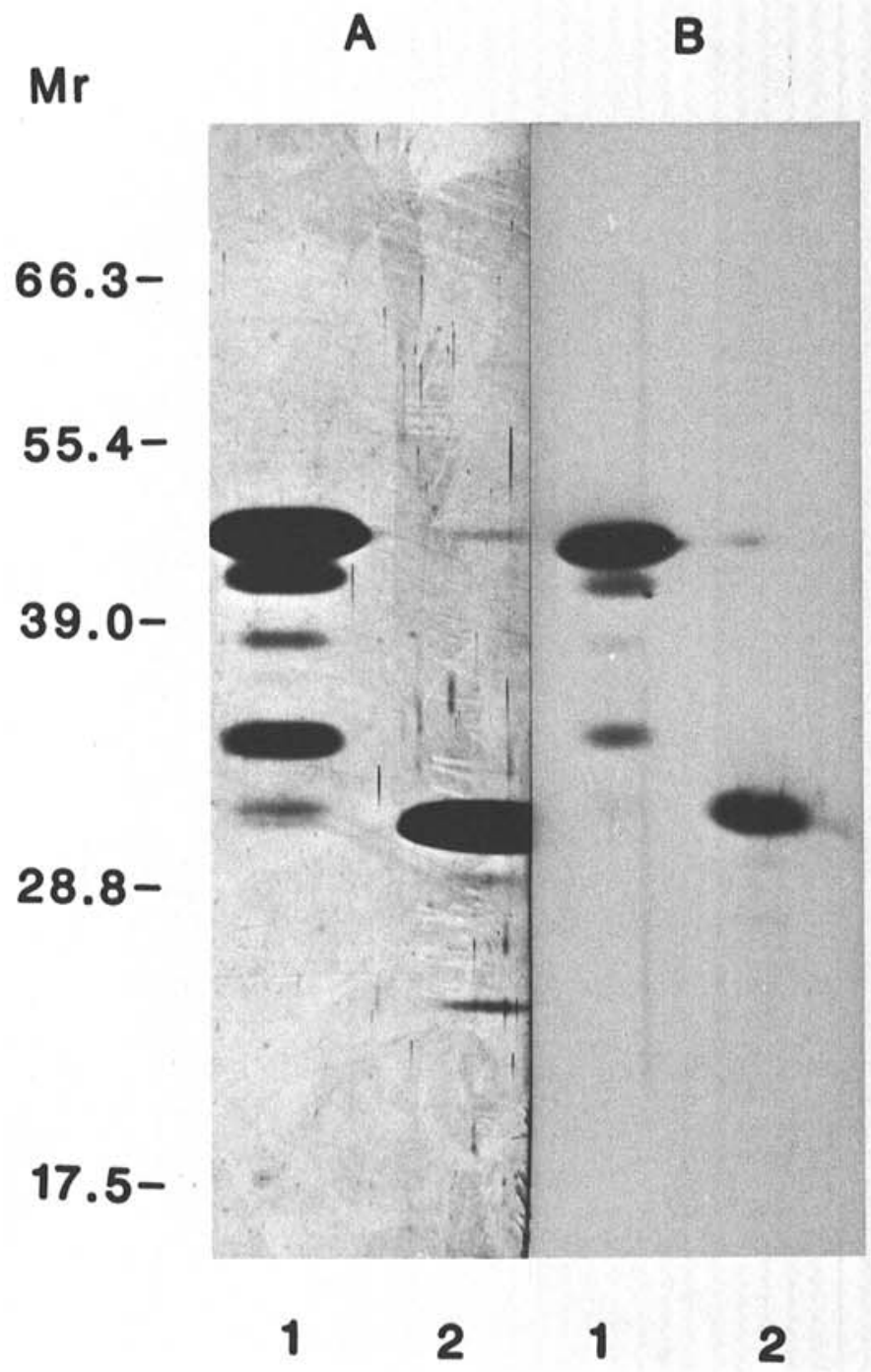

Fig. 4. A, A silver-stained sodium dodecyl sulfate $8-25 \%$ polyacrylamide gradient gel of proteins from virions purified from first (youngest fully expanded) leaves (lane 1) and virions purified from first leaves after trypsin treatment (lane 2). The positions of standard proteins are indicated. B, Western blot of proteins from WSMV virions purified from first leaves (lane 1) and purified virions from first leaves after trypsin treatment (lane 2).
Capsid proteins from different WSMV isolates. Virus was purified by density gradient centrifugation from wheat infected with 13 WSMV isolates. Seven of these were collected in Nebraska from 1956 to 1985, two were from Oklahoma, and one each from Indiana and Illinois. The type strain (PV 57) and McKinney's mild strain (PV 85), which he used for cross-protection tests, were included. Type (PV 57), mild (PV 85), and a 1963 isolate from corn in Nebraska had major $47 \mathrm{kDa}$ proteins with minor $45,43,35$, and $33 \mathrm{kDa}$ proteins. All the other isolates had major $45 \mathrm{kDa}$ proteins with minor $43,42,33$, and $31 \mathrm{kDa}$ proteins. Examples of the protein patterns obtained from these isolates are shown in Figure 5. The apparent sizes were calculated from mobilities in $12 \%$ polyacrylamide gels using a discontinuous buffer (16). Apparent sizes of the major protein varied with gel concentration and increased by about $750 \mathrm{Da}$ for each $1 \%$ decrease in gel concentration (data not shown).

Virus purified from six inbred lines of corn and from six experimental lines of wheat showed the same protein gel electrophoretic patterns as that purified from Michigan Amber wheat.

\section{DISCUSSION}

We have shown that WSMV contains a large capsid protein and varying amounts of smaller proteins. Sherwood (19) has likewise observed the heterogeneity of WSMV capsid protein. We find that the minor proteins are unlikely to reflect a virus mixture since many virus isolates as well as biologically cloned cultures contained similar minor proteins. Additionally, since the minor proteins are independent of the host (corn or wheat) and react in Western blots with antiserum to the virus they are unlikely to be host contaminants. The antiserum did not react detectably with host proteins even when they were at levels far higher than in partially purified virus preparations.

Helical structures should contain a single type of structural subunit with the possible exception of minor proteins at the ends (11). The small (about $31 \mathrm{kDa}$ ) protein appears to be the basic structural unit of the viral helix. The additional roughly $14 \mathrm{kDa}$ of protein in the $45 \mathrm{kDa}$ protein does not seem to be essential for virus structure, although it influences surface properties of the virus. If the "extra" $14 \mathrm{kDa}$ of protein is indeed superficial, the $45 \mathrm{kDa}$ protein and $31 \mathrm{kDa}$ protein forms of the virus, should be equally stable to denaturants. Our experience is consistent with this hypothesis, but we have not tested it in detail. The stability of the "extra" $14 \mathrm{kDa}$ of protein to the selection pressure of continuous virus culture suggests that it serves a biological function.

The increasing prominence of minor, smaller proteins in older leaves suggests that they arise by proteolysis as the leaf ages. Incubating crude extracts from virus-infected tissue at room temperature did not affect the ratio of proteins in the final virus preparation (data not shown) indicating that proteolysis took place in vivo rather than during purification. The sensitivity of the large capsid protein to in vitro proteolysis suggests it could also be sensitive to in vivo proteolysis. If the intermediate-sized capsid proteins that accompany purified WSMV also arise by proteolysis, one might expect low levels of trypsin or other proteases to produce similar intermediates in vitro. So far we have been unable to mimic the in vivo cleavage pattern in vitro, although most common proteases produce the $31 \mathrm{kDa}$ protein form of the virus (unpublished). Alternatively, the "intermediates" could result from action of a virus-specified protease on the viral polyprotein.

The proportion of viral capsid subunit that is removed by proteolysis is unusually large. Dasheen mosaic virus, a potyvirus, has proteins of comparable size to those of WSMV (1) and is the only other filamentous virus that may be cleaved by proteases to the degree of WSMV.

Variation in protein degradation from experiment to experiment complicates physical and biological studies of virions. It is possible that variable capsid protein degradation with leaf age partially explains past difficulties in purifying virus from any but the two youngest wheat leaves. 


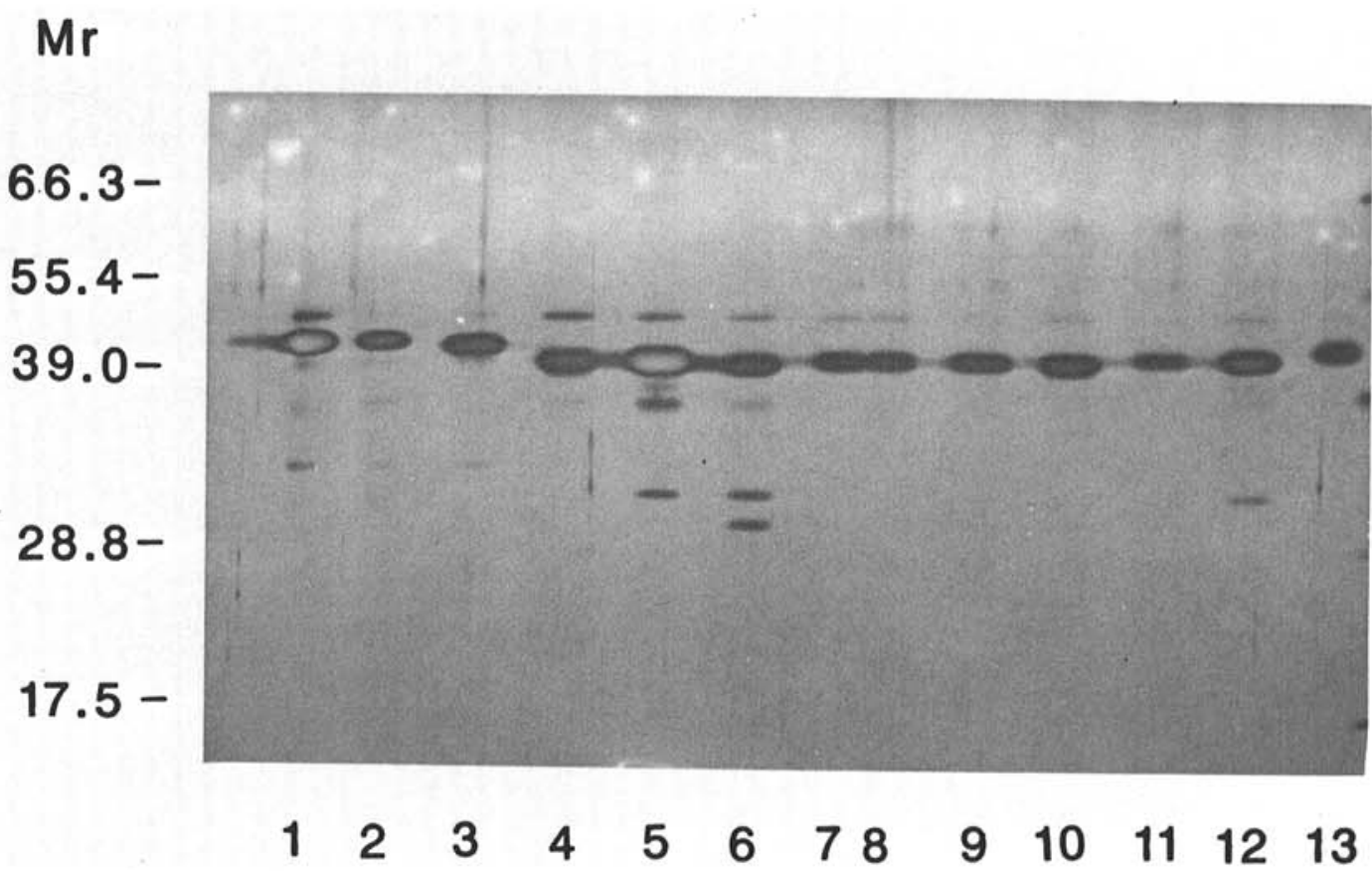

Fig. 5. Gel electrophoretic pattern of capsid proteins from various isolates of wheat streak mosaic virus on an $8-25 \%$ polyacrylamide gel. Lanes 1 and 13 are type strain (PV 57); lane 3 is McKinney's mild strain (PV 85), and lane 12 is Sidney 81 . The positions of standard proteins are indicated. The faint band just above the major virus protein is the large subunit of rubisco.

The large size and protease sensitivity may be fundamental capsid protein properties of potyviruslike mite-transmitted viruses. If other filamentous mite-transmitted viruses have similar large, protease-sensitive capsid subunits, then these properties may be taxonomically significant, and their role in disease biology should be explored.

WSMV strains have been previously distinguishable only by susceptibility of corn hybrids (18) or wheat cultivars (10). Of roughly a hundred field isolates of WSMV obtained from wheat and corn over the last $2 \mathrm{yr}$, all have yielded proteins that comigrate with those of the Sidney 81 isolate (data not shown). The predominance of two size classes of capsid protein among WSMV isolates contrasts with the almost continuous variation in capsid protein size among maize dwarf mosaic virus isolates (14). Studies of additional viruses will be necessary to determine whether or not this is a fundamental biological difference between morphologically similar aphid and mite-transmitted viruses.

The influence of gel concentration on the apparent molecular weight of WSMV capsid protein suggests that the ratio of effective size to charge of the SDS-protein complex differs from that of the standard proteins. Dasheen mosaic virus protein shows similar behavior (1). The sensitivity of size estimates to electrophoretic conditions means that distinguishing strains with small protein size differences requires side-by-side comparisons. It also means that the apparent size of the protein on a gradient gel will depend on how far the protein migrates. It is important not to overinterpret accuracy of gel electrophoretic size estimates. Accurate size determination of WSMV capsid awaits knowledge of the nucleotide sequence of the gene.

\section{LITERATURE CITED}

1. Abo El-Nil, M. M., Zettler, F. W., and Hiebert, E. 1977. Purification, serology and some physical properties of dasheen mosaic virus. Phytopathology 67:1445-1450.

2. Brakke, M. K. 1958. Properties, assay, and purification of wheat streak mosaic virus. Phytopathology 48:439-445.

3. Brakke, M. K. 1963. Photometric scanning of centrifuged density gradient columns. Anal. Biochem. 5:271-283.

4. Brakke, M. K. 1971. Wheat streak mosaic virus. No 48 in: Descriptions of Plant Viruses. Commonw. Mycol. Inst., Assoc. Appl. Biol., Kew, Surrey, England.
5. Brakke, M. K. 1987. Virus diseases of wheat. Pages 585-624 in: Wheat and Wheat Improvement, Agron. Monogr. No. 13, 2nd ed. E. G. Heyne, ed. American Society of Agronomy, Madison, WI.

6. Brakke, M. K., and Ball, E. M. 1968. Purification and antigenicity of wheat streak mosaic virus. Phytopathology 58:963-971.

7. Brakke, M. K., Ball, E. M., Hsu, Y. H., and Langenberg, W. G. 1987. Wheat streak mosaic virus cylindrical inclusion body protein. J. Gen. Virol. 68:281-287.

8. Brakke, M. K., and Van Pelt, N. 1970. Properties of infectious ribonucleic acid from wheat streak mosaic virus. Virology 42:699706.

9. Brakke, M. K., and Van Pelt, N. 1970. Linear-log sucrose gradients for estimating sedimentation coefficients of plant viruses and nucleic acids. Anal. Biochem. 38:56-64.

10. Carroll, T. W., Zaske, S. K., and Brlansky, R. H. 1982. Separation of Montana isolates of wheat streak mosaic virus on Michigan Amber wheat. Plant Dis. 66:916-918.

11. Crick, F. H. C., and Watson, J. D. 1956. Structure of small viruses. Nature (London) 177:473-475.

12. Hiebert, E., and McDonald, J. G. 1976. Capsid protein heterogeneity in turnip mosaic virus. Phytopathology 70:144-150.

13. Hollings, M., and Brunt, A. A. 1981. Potyvirus group. No. 245 in: Descriptions of Plant Viruses. Commonw. Mycol. Inst., Assoc. Appl. Biol., Kew, Surrey, England.

14. Jensen, S. G., Long-Davidson, B., and Seip, L. 1986. Size variation among proteins induced by sugarcane mosaic viruses in plant tissue. Phytopathology 76:528-532.

15. Johnson, D. A., Gautsch, J. W., Sportsman, J. R., and Elder, J. H. 1984. Improved technique utilizing non-fat dried milk for analysis of proteins and nucleic acids transferred to nitrocellulose. Gene Analysis Tech. 1:3-8.

16. Laemmli, U. K. 1970. Cleavage of structural proteins during the assembly of the head of bacteriophage T. Nature (London) 227:680685 .

17. Morrissey, J. H. 1981. Silver stain for proteins in polyacrylamide gels: A modified procedure with enhanced uniform sensitivity. Anal. Biochem. 117:307-310.

18. Niblett, C. L., Newman, M. A., Livers, R. W., and Young, J. R. 1976. Strains of wheat streak mosaic virus. Annu. Wheat Newsl. 22:8586.

19. Sherwood, J. L. 1987. Comparison of a filter paper immunoblotting assay, western blotting and an enzyme linked immunosorbent assay for the detection of wheat streak mosaic virus. J. Phytopathol. 118:6875 .

20. Shukla, D. D., and Ward, C. W. 1989. Structure of potyvirus coat proteins and its application in the taxonomy of the potyvirus group. Advan. Virus Res. 36:273-314. 